\title{
Environmental and Subtidal Fish Assemblage Relationships in Two Different Brazilian Coastal Estuaries
}

\author{
Ana Lúcia Vendel ${ }^{1 *}$, Jean-Luc Bouchereau ${ }^{2}$ and Paulo de Tarso Chaves ${ }^{3}$ \\ ${ }^{l}$ Centro de Ciências Biológicas e Sociais Aplicadas; Universidade Estadual da Paraíba; Rua Monsenhor Walfredo \\ Leal, 487; 58020-540 - João Pessoa - PB - Brasil. ${ }^{2}$ UMR 7138; CNRS IRD MNHN UPMC: Systématique; \\ Adaptation; Evolution; UAG; BP 592; F-97159; Pointe-à-Pitre cedex - France. ${ }^{3}$ Departamento de Zoologia; \\ Universidade Federal do Paraná; 81531-980; C.P.: 19020; Curitiba - PR - Brasil
}

\begin{abstract}
The general structure and organization of the shallow water $(<1.5 \mathrm{~m})$ fish assemblages were studied in two southern Brazilian ecosystems, a bay and a lagoon, under different marine or continental influences. The abiotic factors were measured to define the hydrology of the sites and the biotic descriptors were evaluated to characterize the assemblage structures. Transparency, salinity and organic matter were the abiotic factors which best distinguished the sites. A total richness of 69 species was observed. Ecological guilds, density, diversity and evenness indices values were different at each site. The hydrodynamism and geomorphology determined the structure and the organization of the fish assemblages in these shallow waters. It was observed that the variations in the hydrological attributes generated by the marine or continental water movements were able to alter the conditions in the lagoon more quickly and at more regular frequencies than those in the bay.
\end{abstract}

Key words: fish biodiversity, bay, lagoon, Spartina marsh, Southern Brazil

\section{INTRODUCTION}

The tropical and subtropical mangrove forests are important nurseries for many species of fishes because they offer food and shelter for the larval and juvenile stages (Chaves and Bouchereau, 1999; Vendel et al., 2002). These coastal ecosystems are inhabited by the populations of both marine and freshwater fishes, which display the strategies for the use of these regions. Some marine fishes use the estuaries during their migration to more saline waters. This passage by the estuary facilitates the adaptation of the young fishes to the marine environment (Morin et al., 1992).
The biological zonation inside any single lagoon has been related to the confinement gradient (Guélorget and Perthuisot, 1983), an indicator of the degree of marine influence on the lagoon ecosystems (Mariani, 2001). Guaratuba bay and Barra do Saí lagoon, South of Brazil (Fig. 1) differ in many physiographical characteristics: Guaratuba presents more important values concerning size (area and depth), nature of the communication with the sea (waterway or pass) and freshwater contributions than the lagoon. Beyond the mangrove, on their intertidal zone, these two joint the salt marsh Spartina alterniflora. They are mono specific pioneer marsh that colonizes mainly the shallow, muddy and

*Author for correspondence: analuciavendel@gmail.com 
calm coastal zones. This one is known to constitute a favorable habitat to macro invertebrates (Lana and Guiss, 1991; Bonnet et al., 1994) as well as fish (Robins and Ray, 1986; Edgar and Shaw, 1995).

The ichthyofauna of the deeper zones in Guaratuba bay is relatively well-known (Chaves and Bouchereau, 1999; Chaves and Vendel, 2001). On the other hand, the salt marsh has not yet been subjected to an intensive study. Researches into salt marsh-dominated estuaries indicate that mudflat habitats appear to be transitional zones between the juvenile and adult habitats (Laegdsgaard and Johnson, 1995) and that the high productivity of marshes may contribute significantly to the detrital pool within the estuary through the export of organic matter (Paterson and Whitfield, 1997). Moreover, the biological processes clearly exert important controls on salt marsh sedimentary processes (Torres et al., 2006). The present study aimed to answer the question of whether morphology and hydrodynamism of coastal ecosystems play a role in the organization and functioning of organisms living in the estuary, with fish assemblages as the models. This work aims to evaluate to what extent the physiography of an estuary can be related to the attributes of its fish community, indicating the differences between the ichthyic descriptors of the two estuaries, despite their geographical proximity.

\section{MATERIALS AND METHODS}

\section{Description of the study areas}

Guaratuba bay and Barra do Saí lagoon, estuarine systems in Southern Brazil (Fig.1), each with unique physiographic attributes. Guaratuba bay is wider and deeper than the lagoon and is directly connected to the sea, whereas the lagoon's only link to the sea is through a river. Two rivers flow into Guaratuba bay on the side opposite to the connection between the bay and the sea. The lagoon has a blind bottom, being connected only indirectly to the sea. The two systems have several features in common, such as a semi-diurnal tide with a small $(50 \mathrm{~cm}$ on average) amplitude of variation; a wide mangrove cover in the subtidal zone, notably Laguncularia racemosa (Linnaeus) and, in the intertidal zone, an abundance of the salt marsh Spartina alterniflora Loisel.

Guaratuba bay (Fig. 1) occupies an area of $45 \mathrm{~km}^{2}$

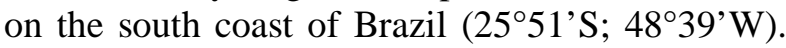

It extends in an easterly-westerly direction for 15 $\mathrm{km}$, with a maximum width of $2.5 \mathrm{~km}$ and a maximum depth of $6 \mathrm{~m}$. On the east, it receives fluvial contribution and communicates with the Atlantic Ocean through a $500 \mathrm{~m}$ wide opening.

The Barra do Saí lagoon is located about $10 \mathrm{~km}$ south of the bay (Fig. 1), has smaller dimensions (area: $0.12 \mathrm{~km}^{2}$ - length: $1.80 \mathrm{~km}$, width: 0.030 $\mathrm{km}$ ) and is shallower (maximum depth: $2 \mathrm{~m}$ ). Its communication with the sea occurs though the SaíGuaçu River, by means of a $200 \mathrm{~m}$ long by $10 \mathrm{~m}$ wide channel, the only pathway for the entrance or exit of marine and continental waters. Due to the large dimension of the bay, two sectors were distinguished, previously recognized by Bouchereau and Chaves (2003) as areas with the peculiar attributes for the ichthyofauna of deeper waters. These were designated $\mathrm{C}$ for the most interior sector at West under continental influence, and $\mathrm{M}$ for the Eastern sector under marine influence, close to the connection with the sea (Fig. 1). Only one sector, S, was considered for the lagoon (Fig. 1).

\section{Sampling and data processing}

In each of the three sectors, the ichthyofauna was sampled in the water column at a depth between 0 and $1.5 \mathrm{~m}$ at six stations: $\mathrm{C} 1$ to $\mathrm{C} 6$ (continental), M1 to M6 (marine) in the bay and S1 to S6 in the lagoon. Beach seines $2.5 \mathrm{~m}$ high, with a $5 \mathrm{~mm}$ mesh were used; $30 \mathrm{~m}$ long for the bay and $22 \mathrm{~m}$ long for the lagoon where the topography did not permit the use of a net as long as in the bay. During 10 minutes, the sampling was carried out in the bay bimonthly, from April 1999 to February 2000 , and in the lagoon monthly from December 2000 to November 2001. At each point, the salinity (g.l-1), temperature $\left({ }^{\circ} \mathrm{C}\right), \quad \mathrm{pH}$ and transparency $(\mathrm{cm})$ were measured, the first evaluated using refractometer, thermometer and digital $\mathrm{pH}$ meter, respectively; the latter evaluated as the depth where the Secchi disk could no longer be seen. The sediments obtained from the 18 points were analyzes in the 'Laboratório de Sedimentologia' of the Federal University of Paraná, Brazil. The proportion of organic matter in the suspension and the granulometric fractions of silt, clay and sand were obtained using the methodology of Folk and Ward (Folk and Ward, 1957). The transparency data together with the sediment analysis data were used to interpret the suspension matter data. 


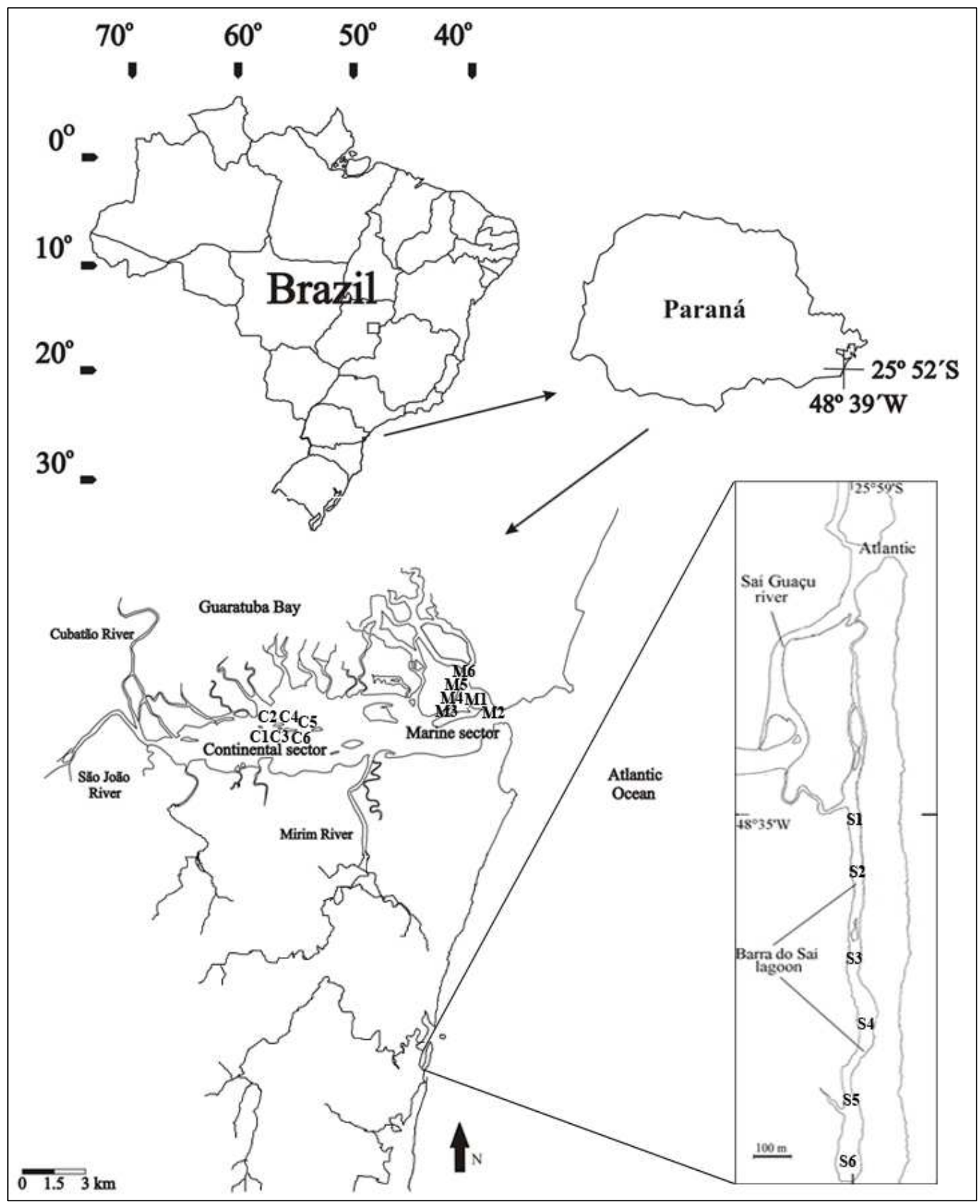

Figure 1 - Geographic location of Guaratuba bay and the six sampling stations in each of the two studied sectors: continental C1 to C6 and marine M1 to M6. Detail of Barra do Saí lagoon and the six sampling stations $\mathrm{S} 1$ to $\mathrm{S} 6$.

The fishes were identified, counted and weighed. In order to compare the density data between the two environments, catch per unit of effort (CPUE) was estimated in each one considering the net length in the lagoon was $8 \mathrm{~m}$ smaller than that used in the bay. The net casts in the lagoon were grouped bimonthly by calculating the mean of the species sets obtained in two consecutive months, thus corresponding to the bimonthly effort in the bay. The descriptors, species richness (RS), family richness (RF), Diversity (H') and evenness (E) were calculated and tested post-hoc by Tukey's 
multiple comparison test. The species were grouped into the following ecological guilds (Elliott and Dewailly, 1995 modified): guild R or resident (also sedentary): species that complete their whole life-cycle within the estuarine environment; guild $\mathrm{M}$ or marine migrants: species that remain in the estuary for a trophic or reproductive ecophase; guild $\mathrm{O}$ or occasional species from marine $(\mathrm{Om})$ or freshwater (Of) origin, whose the presence in the estuary was irregular. This classification includes the migration, life cycle and frequency by which the species occur in estuaries. In view of the lack of previous studies for all species, for some of them it was based on the deductions from individuals' distribution, size and density during the duration of this study.

To make the comparison between the two possible habitats, the biotic and abiotic data were grouped by the unweighted pair group method with arithmetic mean (UPGMA) and by Gower's similarity coefficient, which considered the absence of a species in the samples. The ANOVA applied to the six stations of each of the three sectors permit combining the density data with the abiotic data for the temporal analysis using the factorial correspondence analysis - FCA (Legendre and Legendre, 1984). The FCA was carried out on the species sets and their respective status $(R, M$, Om and Of). Initially, this was done for the group of captured species and their densities. Subsequently, the FCA was carried out only for the density that had a greater or equal value than the mean contribution of each species, which was supplied by the actual analysis (Legendre and Legendre, 1984).

\section{RESULTS}

Results of the FCA applied to all the abiotic variables obtained in monthly samples (Fig. 2) indicated that the transparency, salinity and percentage of organic matter and silt were the most significant. When comparing the samples obtained in the marine sector to those of the continental and lagoon sectors, the first axis (contribution: 79\%) was governed by a negative gradient of suspended matter whereas the second $(20 \%)$ by a positive gradient of salinity. This latter variable had a greater influence over the marine sector of Guaratuba and the lagoon in Barra do Saí in the continental sector of the bay.

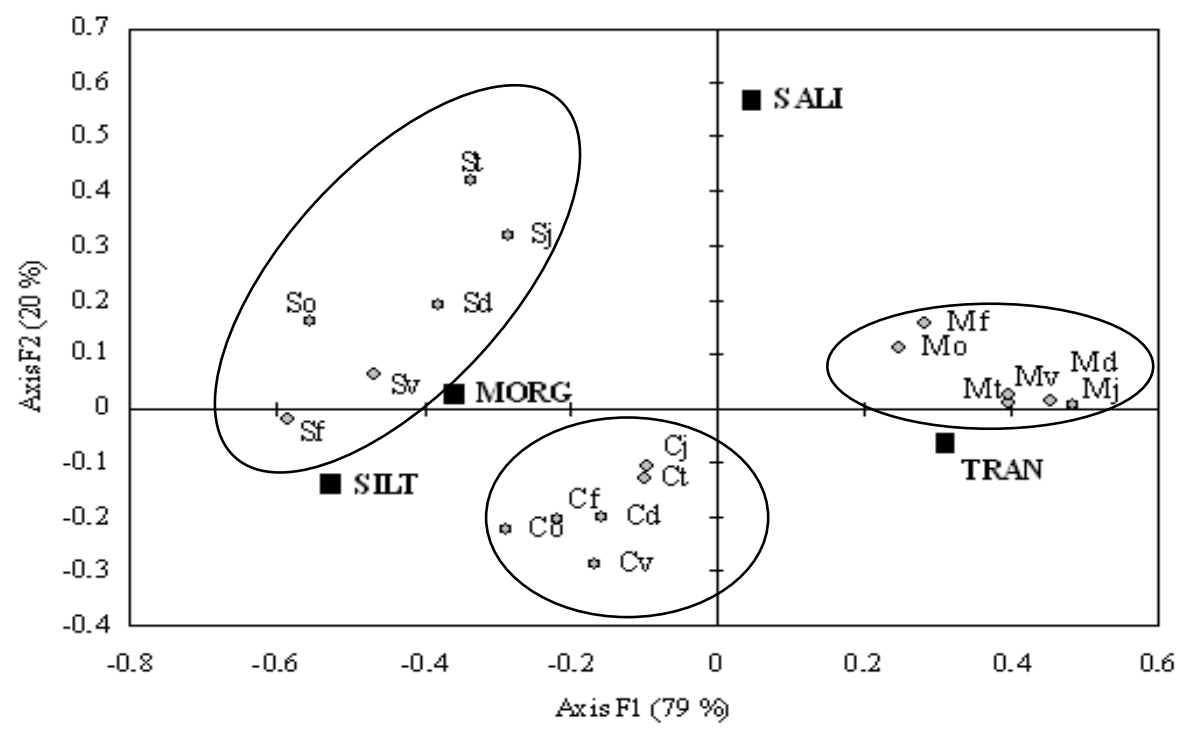

Figure 2 - Factorial correspondence analysis considering the abiotic variables: transparency (TRAN), salinity (SALI), organic material (MORG) and SILT in the six sampling stations of both site: continental $\mathrm{C}$ and marine $\mathrm{M}$ sectors in Guaratuba bay, and in Barra do Saí S; v: April; j: June; t: August; o: October; d: December; f: February. 
Table 1 - Inventoried species (+), according to the taxonomic order of Nelson (1994) in the six studied stations in each site and their respective status after the ecological guilds $(\mathrm{G})$ : resident $\mathrm{R}$; marine migrant $\mathrm{M}$; marine occasional Om; freshwater occasional Of. R: References.

\begin{tabular}{|c|c|c|c|c|c|c|c|c|c|c|c|c|c|c|c|c|c|c|c|c|}
\hline \multirow{2}{*}{ Taxa } & \multirow{2}{*}{$\mathbf{G}$} & \multirow{2}{*}{$\mathbf{R}$} & \multicolumn{6}{|c|}{ Continental sector } & \multicolumn{6}{|c|}{ Marine sector } & \multicolumn{6}{|c|}{ Barra do Saí } \\
\hline & & & 1 & 2 & 3 & 4 & 5 & 6 & 1 & 2 & 3 & 4 & 5 & 6 & 1 & 2 & 3 & 4 & 5 & 6 \\
\hline Anchoa lyolepis & M & 30 & - & + & - & + & - & - & + & + & + & + & + & + & - & - & - & - & - & - \\
\hline A. januaria & $\mathrm{R}$ & 1 & + & + & + & + & + & + & + & + & + & + & + & + & + & + & - & + & + & + \\
\hline Anchoviella lepidentostole & M & 19 & + & + & + & + & + & - & + & + & + & + & - & - & - & - & - & - & - & - \\
\hline Cetengraulis edentulus & M & 19 & - & + & - & - & - & - & - & - & - & - & - & - & - & - & - & - & - & - \\
\hline Lycengraulis grossidens & M & 19 & + & - & - & + & + & + & - & . & - & - & + & + & - & - & - & - & - & + \\
\hline Harengula clupeola & M & 11 & + & - & - & - & - & - & + & + & + & + & + & + & - & - & - & - & - & + \\
\hline Opisthonema oglinum & M & 18 & + & + & + & - & - & - & + & + & + & + & + & + & - & - & - & - & - & - \\
\hline Sardinella brasiliensis & M & 31 & + & + & - & - & - & - & + & + & - & + & - & + & - & - & - & - & - & - \\
\hline Genidens genidens & $\mathrm{R}$ & 9 & - & - & - & - & - & - & - & - & - & - & - & - & + & + & + & + & + & + \\
\hline Synodus foetens & Om & 11 & - & - & - & - & - & - & + & - & - & + & + & + & - & - & - & - & - & - \\
\hline Mugil curema & $\mathrm{M}$ & 1 & - & + & - & - & - & - & + & + & + & + & - & + & + & + & + & + & - & + \\
\hline M. gaimardianus & M & 13 & - & - & - & - & - & - & - & + & - & - & + & - & - & - & - & - & - & - \\
\hline M. platanus & M & 13 & - & - & - & - & - & - & - & - & - & - & & - & + & + & - & + & + & + \\
\hline Mugil sp. & M & & - & - & + & - & - & - & + & + & + & + & - & + & + & + & + & - & + & + \\
\hline Atherinella brasiliensis & $\mathrm{R}$ & 1 & + & + & + & + & + & + & + & + & + & + & + & + & + & + & + & + & + & + \\
\hline Strongylura marina & M & 17 & - & - & - & - & - & - & + & - & + & + & - & + & + & + & + & + & + & + \\
\hline S. tітиси & M & 29 & - & - & - & - & - & - & + & + & + & - & + & + & + & - & - & - & - & - \\
\hline Strongylura sp. & M & & - & - & - & - & - & - & - & + & - & - & + & + & - & - & - & - & - & - \\
\hline Hemirhamphus brasiliensis & M & 11 & - & - & - & - & - & - & - & - & - & - & - & - & - & - & - & - & - & + \\
\hline Hyporhamphus unifasciatus & M & 28 & - & - & - & + & + & - & - & - & - & - & - & + & - & - & - & + & - & - \\
\hline Poecilia vivipara & Of & 15 & - & - & - & - & - & - & 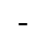 & - & & - & - & 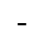 & + & + & + & - & - & + \\
\hline Syngnathus rousseau & $\mathrm{Om}$ & 30 & - & - & - & - & + & - & - & - & - & - & - & - & - & - & - & - & - & - \\
\hline Prionotus punctatus & Om & 32 & - & - & - & - & - & - & - & + & - & - & - & - & - & - & - & - & - & - \\
\hline Centropomus parallelus & M & 1 & + & + & + & - & + & - & - & - & - & + & - & - & + & + & + & + & + & + \\
\hline C. undecimalis & M & 4 & - & - & - & - & - & - & - & - & - & - & - & - & - & + & + & + & + & - \\
\hline Diplectrum radiale & $\mathrm{Om}$ & 4 & - & - & - & - & - & - & - & + & - & - & - & - & - & - & - & - & - & - \\
\hline Epinephelus nigrittus & $\mathrm{Om}$ & 7 & - & - & - & - & - & - & - & - & - & - & - & - & - & + & - & - & - & - \\
\hline Epinephelus sp. & $\mathrm{Om}$ & & - & - & - & - & - & - & - & - & - & - & - & - & + & - & - & - & - & - \\
\hline Mycteroperca sp. & Om & & - & - & - & - & - & - & - & - & 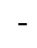 & - & - & - & + & - & - & - & - & + \\
\hline Pomatomus saltatrix & $\mathrm{Om}$ & 20 & + & - & + & - & - & - & + & + & - & - & - & + & - & - & - & - & - & - \\
\hline Chloroscombrus chrysurus & $\mathrm{Om}$ & 5 & - & - & - & - & - & - & & - & + & + & + & - & - & - & - & - & - & - \\
\hline Caranx latus & $\mathrm{Om}$ & 3 & - & - & - & - & - & - & + & - & - & - & - & - & - & + & - & - & - & + \\
\hline Oligoplites palometa & Om & 23 & - & - & - & + & - & - & - & - & - & - & - & - & - & - & - & - & - & - \\
\hline O. saurus & $\mathrm{Om}$ & 24 & + & + & - & + & + & + & - & - & + & - & + & - & - & - & - & + & + & - \\
\hline Selene vomer & Om & 17 & - & - & + & - & - & - & - & - & - & - & - & + & - & - & - & - & - & - \\
\hline Diapterus rhombeus & $\mathrm{M}$ & 27 & + & + & + & + & + & + & - & - & - & - & + & + & + & + & + & + & + & + \\
\hline Eucinostomus argenteus & M & 1 & + & + & + & + & + & + & + & + & + & + & + & + & + & + & + & + & + & + \\
\hline E. gula & M & 1 & + & - & + & - & - & - & - & + & - & + & + & + & - & - & - & + & + & + \\
\hline E. lefroyi & M & 24 & - & - & - & + & - & - & - & - & - & + & - & - & - & - & - & - & - & - \\
\hline E. melanopterus & M & 1 & - & - & - & - & - & - & - & - & - & - & - & + & + & + & + & + & + & + \\
\hline Eugerres brasilianus & M & 5 & - & - & - & - & - & - & - & - & - & - & - & - & - & + & - & + & - & + \\
\hline Bairdiella ronchus & $\mathrm{R}$ & 22 & - & + & - & - & - & - & - & - & - & - & - & - & - & - & - & - & - & - \\
\hline Micropogonias furnieri & $\mathrm{M}$ & 12 & - & - & - & - & - & - & - & - & - & - & - & - & + & + & - & - & - & - \\
\hline Ophioscion punctatissimus & Om & 14 & - & - & - & - & - & - & - & - & - & - & - & - & - & - & + & - & - & - \\
\hline Stellifer rastrifer & $\mathrm{M}$ & 33 & + & - & - & - & - & - & - & - & - & - & - & - & - & - & - & - & - & - \\
\hline Geophagus brasiliensis & Of & 8 & - & - & - & - & - & - & - & - & - & - & - & - & - & - & - & - & + & - \\
\hline Guavina guavina & $\mathrm{R}$ & 10 & - & - & - & - & - & - & - & - & - & - & - & - & - & + & - & + & - & - \\
\hline Bathygobius soporator & $\mathrm{R}$ & 6 & + & + & + & + & + & + & - & - & - & - & - & - & - & + & + & + & + & + \\
\hline Ctenogobius shufeldti & $\mathrm{R}$ & 17 & + & - & - & + & + & + & - & - & - & - & - & - & + & + & + & + & + & + \\
\hline C. smaragdus & $\mathrm{R}$ & 30 & + & + & + & + & + & + & - & + & - & - & - & - & + & + & - & + & + & + \\
\hline C. stigmaticus & $\mathrm{R}$ & 17 & + & + & + & + & + & + & - & - & - & + & - & - & - & - & - & - & - & - \\
\hline Gobioides broussonnetti & $\mathrm{R}$ & 30 & + & - & - & - & - & - & - & - & - & - & - & - & - & - & - & - & - & - \\
\hline
\end{tabular}


(cont. Table 1)

\begin{tabular}{|c|c|c|c|c|c|c|c|c|c|c|c|c|c|c|c|c|c|c|c|c|}
\hline \multirow{2}{*}{ Taxa } & \multirow{2}{*}{$\mathbf{G}$} & \multirow{2}{*}{$\mathbf{R}$} & \multicolumn{6}{|c|}{ Continental sector } & \multicolumn{6}{|c|}{ Marine sector } & \multicolumn{6}{|c|}{ Barra do Saí } \\
\hline & & & 1 & 2 & 3 & 4 & 5 & 6 & 1 & 2 & 3 & 4 & 5 & 6 & 1 & 2 & 3 & 4 & 5 & 6 \\
\hline Gobionellus oceanicus & $\mathrm{R}$ & 6 & - & - & + & - & - & + & 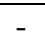 & & & - & - & - & + & - & - & + & + & + \\
\hline G. stomatus & $\mathrm{R}$ & 30 & - & + & - & - & - & - & - & - & - & - & - & - & + & + & + & - & - & - \\
\hline Microgobius meeki & $\mathrm{R}$ & 30 & + & - & - & - & + & - & - & - & - & - & - & - & - & - & - & - & - & - \\
\hline Chaetodipterus faber & $\mathrm{R}$ & 1 & - & - & - & - & - & - & - & + & + & + & + & - & - & - & - & - & - & - \\
\hline Scomberomorus brasiliensis & $\mathrm{Om}$ & 21 & - & + & - & - & - & - & - & - & - & + & - & - & - & - & - & - & - & - \\
\hline Citharichthys arenaceus & $\mathrm{R}$ & 26 & + & + & + & + & + & + & + & + & + & + & + & + & + & + & + & + & + & + \\
\hline C. spilopterus & $\mathrm{R}$ & 26 & + & - & - & - & - & + & $T$ & & + & + & + & - & + & - & + & + & + & + \\
\hline Etropus crossotus & $\mathrm{M}$ & 2 & - & + & + & - & - & - & + & + & - & - & - & - & - & - & - & - & - & - \\
\hline Trinectes microphtalmus & $\mathrm{Om}$ & 2 & - & - & - & - & - & - & - & - & - & - & - & - & - & + & - & - & - & - \\
\hline T. paulistanus & $\mathrm{Om}$ & 5 & - & - & - & - & - & - & - & + & - & - & - & - & - & - & - & - & - & - \\
\hline Achirus declivis & $\mathrm{Om}$ & 2 & - & - & - & - & - & - & - & - & - & - & - & - & + & - & - & - & - & - \\
\hline A. lineatus & $\mathrm{M}$ & 25 & - & + & - & - & - & - & + & - & - & - & - & - & + & + & + & + & + & - \\
\hline Symphurus tesselatus & $\mathrm{Om}$ & 2 & - & - & - & - & + & - & - & - & - & - & - & - & - & - & - & - & - & + \\
\hline Stephanolepis hispidus & $\mathrm{Om}$ & 16 & - & - & - & - & - & - & - & + & + & - & - & + & - & - & - & - & - & - \\
\hline Cyclichthys spinosus & $\mathrm{Om}$ & 2 & - & - & - & - & + & + & + & + & + & - & - & - & - & - & - & - & + & + \\
\hline Sphoeroides greeleyi & $\mathrm{R}$ & 1 & - & - & - & - & - & - & + & + & + & + & + & + & + & + & + & + & + & + \\
\hline S. testudineus & $\mathrm{R}$ & 1 & + & + & + & + & + & + & + & + & + & + & + & + & + & + & + & + & + & + \\
\hline
\end{tabular}

1-Adams, 1976; 2-Figueiredo and Menezes, 2000; 3-Silvano, 2001; 4-Sierra et al., 1994; 5-Cervigón et al., 1992; 6-Maugé, 1986; 7Heemstra and Randall, 1993; 8-Axelrod and Schultz, 1990; 9-Mazzoni et al., 2000; 10-Cervigón, 1994; 11-Randall, 1967; 12-Robert and Chaves, 2001; 13-Menezes and Figueiredo, 1985; 14-Chao, 1978; 15-Aranha and Caramaschi, 1997; 16-Adams, 1976; 17-Robins and Ray, 1986; 18-Whitehead, 1985; 19-Whitehead et al., 1988; 20-Juanez et al., 1993; 21-Collette and Nauen, 1983; 22-Vendel and Chaves, 1998; 23-Duque-Nivea et al., 1996; 24-Menezes and Figueiredo, 1980; 25-Keith et al., 2000; 26-Chaves and Vendel, 1997; 27-Austin, 1971; 28-Collette, 1978; 29-Pauly, 1991; 30-Present study; 31-Saccardo et al., 1988; 32-Miller and Richards, 1978; 33-Chaves and Vendel, 1998.

The densities obtained in the lagoon and in the bay, the continental and marine sectors were respectively 2,066 and 49,002, 32,042, 16,960 individuals. The corresponding density for each sector was $10.04 \mathrm{~g}$ and $109.19 \mathrm{~g}, 60.34 \mathrm{~g}, 48.85 \mathrm{~g}$. The total species richness was 69 (Table 1); 41 species were obtained in the lagoon and 50 in the bay, of which 38 were from the marine sector and 39 from the continental one (Fig. 3). The species and family richness were higher in Guaratuba bay (50 and 25, respectively) than in Barra do Saí lagoon (41 and 21, respectively). In the general survey, the ecological guilds (Fig. 4) were divided as follows: 18 resident species (26.1\%), 28 migrant species $(40.6 \%), 21$ marine occasional species (30.4\%) and 2 freshwater occasional species $(2.9 \%)$. Independent of the study area, the migrants represent about $50 \%$ of the species richness (Figs 3, 4).

Regarding the used effort, the density and biomass were 57 individuals and $279 \mathrm{~g}$ respectively in Barra do Saí lagoon, 681 individuals and 1,518 g in Guaratuba bay, separated into 471 individuals and $1,358 \mathrm{~g}$ in the marine sector and 890 individuals and $1,675 \mathrm{~g}$ in the continental one. The respective density relationship was: $4.86 \mathrm{~g}$ for the lagoon and $2.23 \mathrm{~g}$ for the bay $(\mathrm{C}: 1.88 \mathrm{~g}$ and $\mathrm{M}$ : $2.88 \mathrm{~g}$ ). Individual data per station in each site were similar to species richness, while density and CPUE were associated to large capture (Table 2).

The hierarchical clustering of the fish whose presence was observed in the 18 samples (Table 1 ), separated the lagoon and the bay at the 0.65 threshold into three very distinct groups (Fig. 5) which corresponded to the three study areas: Barra do Saí lagoon and the two sectors of Guaratuba bay under marine and continental influence. Moreover, these three groups were also maintained when the species richness was considered as a function of the samples (Fig. 6). There was a negative gradient from the marine sector of the bay to the continental one, with intermediary values for the Barra do Saí lagoon.

Independent of the station, the $\mathrm{H}^{\prime}$ and $\mathrm{E}$ indices were always greater in the Barra do Saí lagoon (3.87 and 0.71) than in the two sectors of Guaratuba: M (2.65 and 0.50) and C (0.38 and 0.07). Throughout the year, these values were greater in Barra do Saí lagoon, but had an opposite variation in the two sectors in the bay, except from December to February, when they increased in both the sectors (Table 3). When tested, these 
indices showed significant differences $(p<0.05)$ in time and space, between the lagoon and the two sectors in the bay, but did not show significant differences in time between the marine and continental sectors of Guaratuba bay.

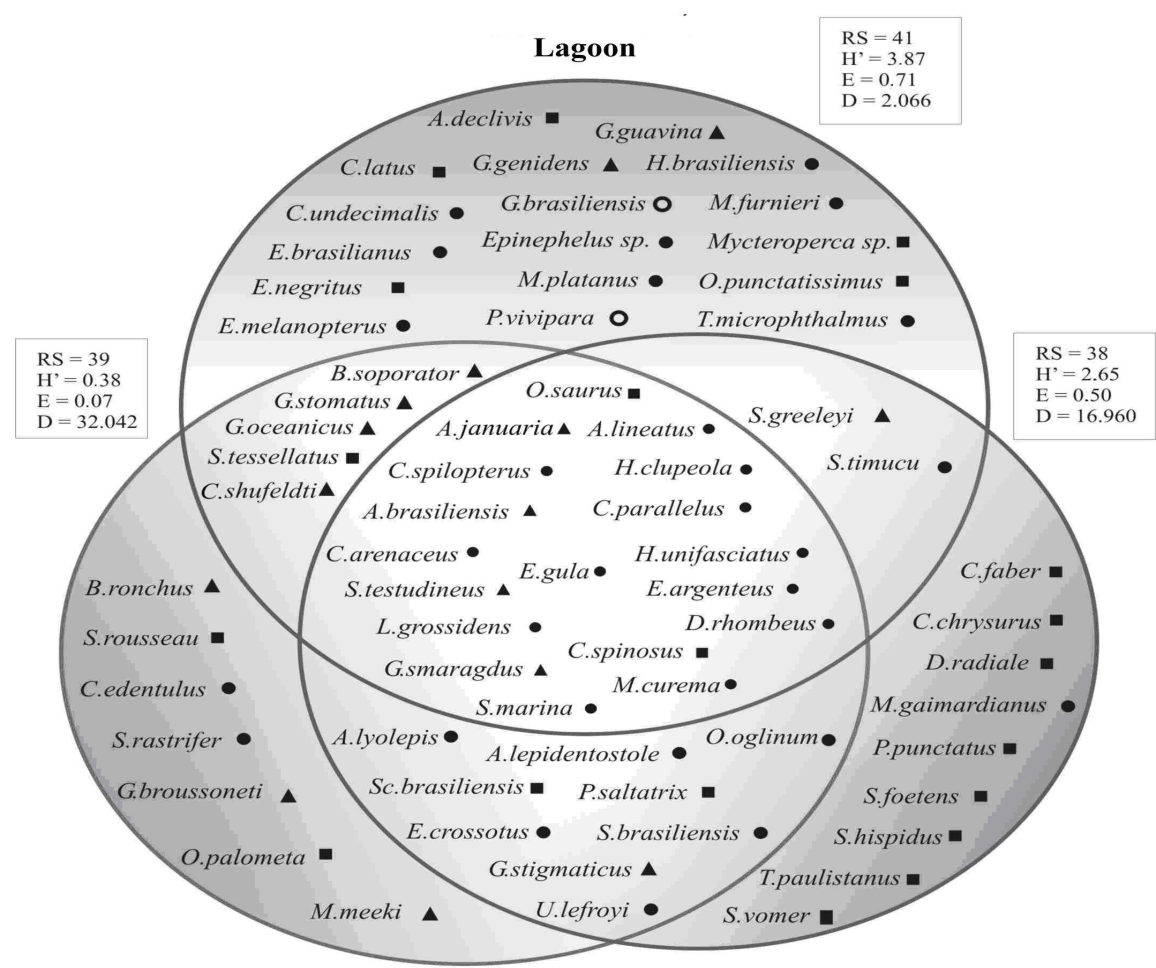

Bay Continental sector

Bay Marine sector

- Residen

- Migrant

ム Marine occasional

o Freshwater occasional

Figure 3 - Sampling species diagram and their ecological guilds in the continental $\mathrm{C}$ and marine $\mathrm{M}$ sectors of the Guaratuba bay, and in the Barra do Saí lagoon; RS: species richness; H': diversity; E: evenness; D: density.

Table 2 - Species richness, density and CPUE (catch per unit of effort) in the six studied stations in each site, continental C and marine M, both in Guaratuba bay and Barra do Saí S.

\begin{tabular}{ccccccc}
\hline Station & $\mathbf{1}$ & $\mathbf{2}$ & $\mathbf{3}$ & $\mathbf{4}$ & $\mathbf{5}$ & $\mathbf{6}$ \\
\hline $\mathbf{C}$ & 23 & 22 & Species richness & & \\
$\mathbf{M}$ & 23 & 27 & 20 & 17 & 19 & 23 \\
$\mathbf{S}$ & 26 & 27 & 20 & 25 & 24 & 29 \\
\hline $\mathbf{C}$ & 8,653 & 1,981 & 5,035 & 818 & 16,995 & 10,212 \\
$\mathbf{M}$ & 2,298 & 2,245 & 1,797 & 5,957 & 6,200 & 4,630 \\
$\mathbf{S}$ & 495 & 366 & 520 & 227 & 354 & 335 \\
\hline $\mathbf{C}$ & 288.4 & 66.0 & 167.8 & 27.3 & 566.5 & 340.4 \\
$\mathbf{M}$ & 76.6 & 74.8 & 59.9 & 198.6 & 206.7 & 154.6 \\
$\mathbf{S}$ & 22.5 & 16.6 & 23.6 & 10.3 & 16.1 & 15.2 \\
\hline
\end{tabular}




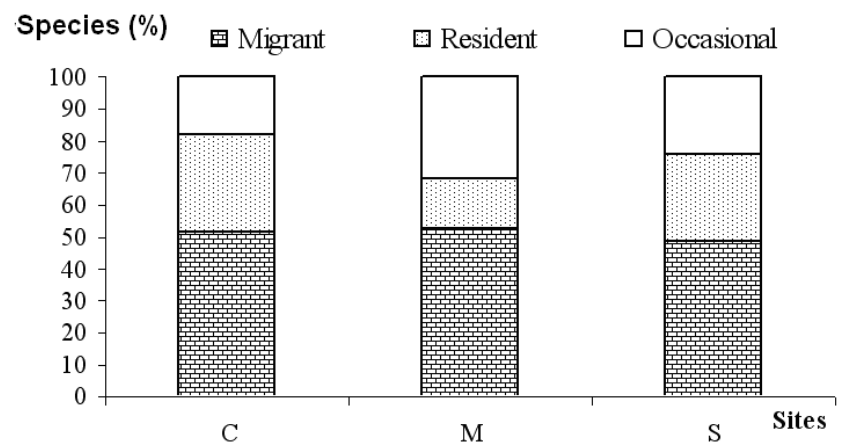

Figure 4 - Relative frequency in number of the ecological guilds according to the sites: continental $\mathrm{C}$ and marine M sectors of the Guaratuba bay, and Barra do Saí lagoon S.

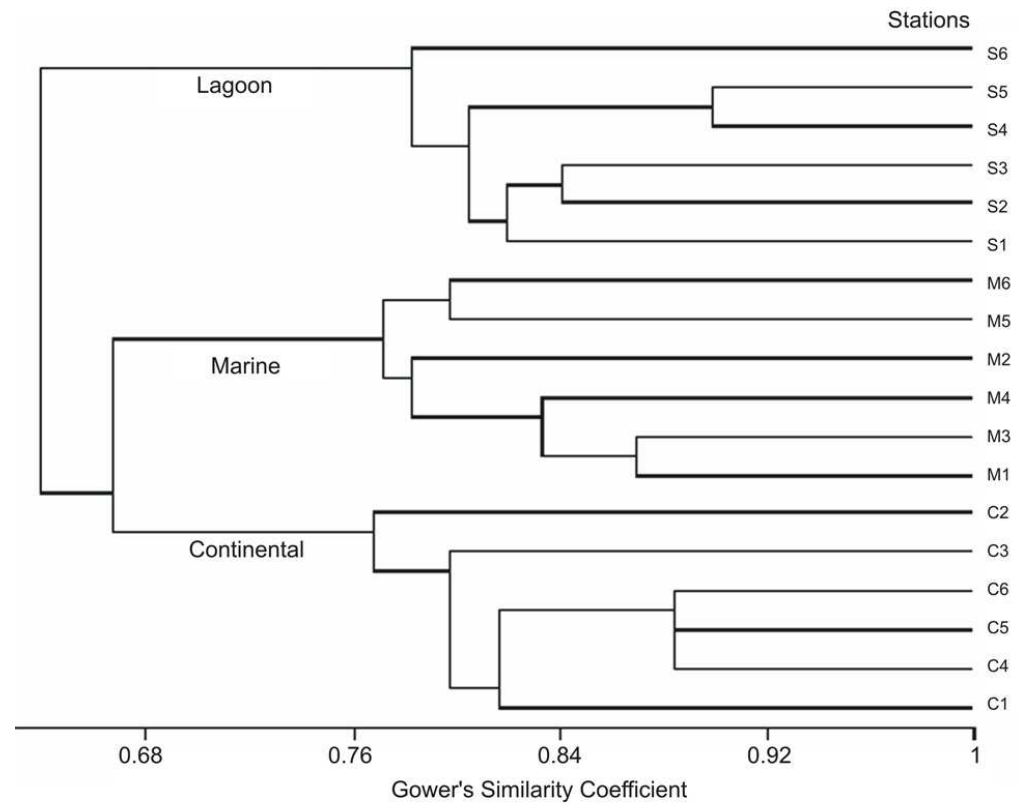

Figure 5 - Hierarchical classification of the 18 sampling stations, according to the species presence: continental $\mathrm{C} 1$ to $\mathrm{C} 6$ and marine M1 to M6 sectors of the Guaratuba bay and in Barra do Saí lagoon S1 to S6

Table 3 - Diversity H' and evenness E indices in each studied site continental C and marine M, both in Guaratuba bay and Barra do Saí $\mathrm{S}$ according to the sampling station and month.

\begin{tabular}{|c|c|c|c|c|c|c|c|c|c|c|c|c|c|c|}
\hline Station & \multicolumn{2}{|c|}{1} & \multicolumn{2}{|c|}{2} & \multicolumn{2}{|c|}{ J } & \multicolumn{2}{|c|}{ 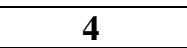 } & \multicolumn{2}{|c|}{5} & \multicolumn{2}{|c|}{6} & \multicolumn{2}{|c|}{ Total } \\
\hline Index & $\mathbf{H}^{\prime}$ & $\mathbf{E}$ & $\mathbf{H}^{\prime}$ & $\mathbf{E}$ & H' & $\mathbf{E}$ & H' & $\mathbf{E}$ & H' & $\mathbf{E}$ & H' & $\mathbf{E}$ & H' & $\mathbf{E}$ \\
\hline $\mathrm{C}$ & 0.37 & 0.08 & 0.75 & 0.18 & 0.14 & 0.03 & 0.43 & 0.10 & 1.71 & 0.41 & 0.21 & 0.06 & 0.38 & 0.07 \\
\hline M & 2.20 & 0.52 & 2.50 & 0.59 & 1.38 & 0.33 & 2.22 & 0.48 & 2.68 & 0.60 & 1.66 & 0.38 & 2.65 & 0.50 \\
\hline $\mathrm{S}$ & 3.62 & 0.79 & 3.84 & 0.84 & 2.57 & 0.59 & 3.39 & 0.73 & 3.41 & 0.75 & 3.78 & 0.79 & 3.87 & 0.71 \\
\hline Month & \multicolumn{2}{|c|}{ April } & \multicolumn{2}{|c|}{ June } & \multicolumn{2}{|c|}{ August } & \multicolumn{2}{|c|}{ October } & \multicolumn{2}{|c|}{ December } & \multicolumn{2}{|c|}{ February } & \multicolumn{2}{|c|}{ Total } \\
\hline Index & $\mathbf{H}^{\prime}$ & $\mathbf{E}$ & $\mathbf{H}^{\prime}$ & $\mathbf{E}$ & $\mathbf{H}^{\prime}$ & $\mathbf{E}$ & $\mathbf{H}^{\prime}$ & $\mathbf{E}$ & H' & $\mathbf{E}$ & H' & $\mathbf{E}$ & H' & $\mathbf{E}$ \\
\hline $\mathrm{C}$ & 0.02 & 0.01 & 0.45 & 0.11 & 0.29 & 0.08 & 1.22 & 0.34 & 1.20 & 0.35 & 2.57 & 0.53 & 0.38 & 0.07 \\
\hline M & 2.91 & 0.67 & 0.99 & 0.26 & 1.89 & 0.50 & 1.59 & 0.57 & 0.79 & 0.20 & 2.34 & 0.49 & 2.65 & 0.50 \\
\hline $\mathrm{S}$ & 3.23 & 0.75 & 3.23 & 0.79 & 3.44 & 0.80 & 3.61 & 0.81 & 3.12 & 0.65 & 3.58 & 0.73 & 3.87 & 0.71 \\
\hline
\end{tabular}


The results of the FCA using density of all species indicated that the density explained only $45 \%$ of the total inertia, whereas the contribution of the sets explained $54 \%$ of the inertia, which was why it was maintained in the present study. With the set of 24 species retained in the analysis, it reached
$55 \%$ of inertia (Fig. 7). The first axis explained $31 \%$ of the information and reflected a gradient between the autumn/winter and spring/summer, opposing the continental (C) and marine (M) sectors of the bay to the lagoon ones (S).

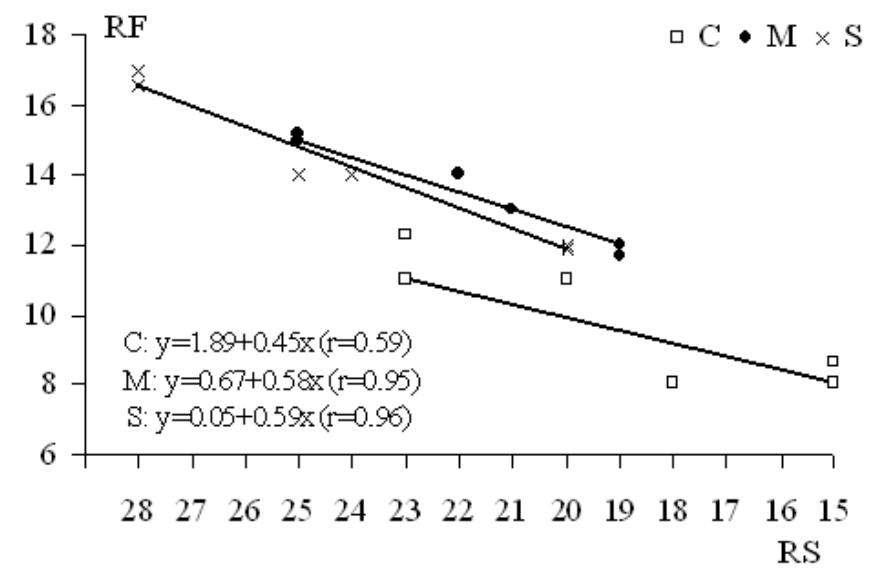

Figure 6 - Relation between species (RS) and family (RF) richness in the continental $\mathrm{C}$ and marine $\mathrm{M}$ sectors of the Guaratuba bay and $\mathrm{S}$ in Barra do Saí lagoon and regression relationship.

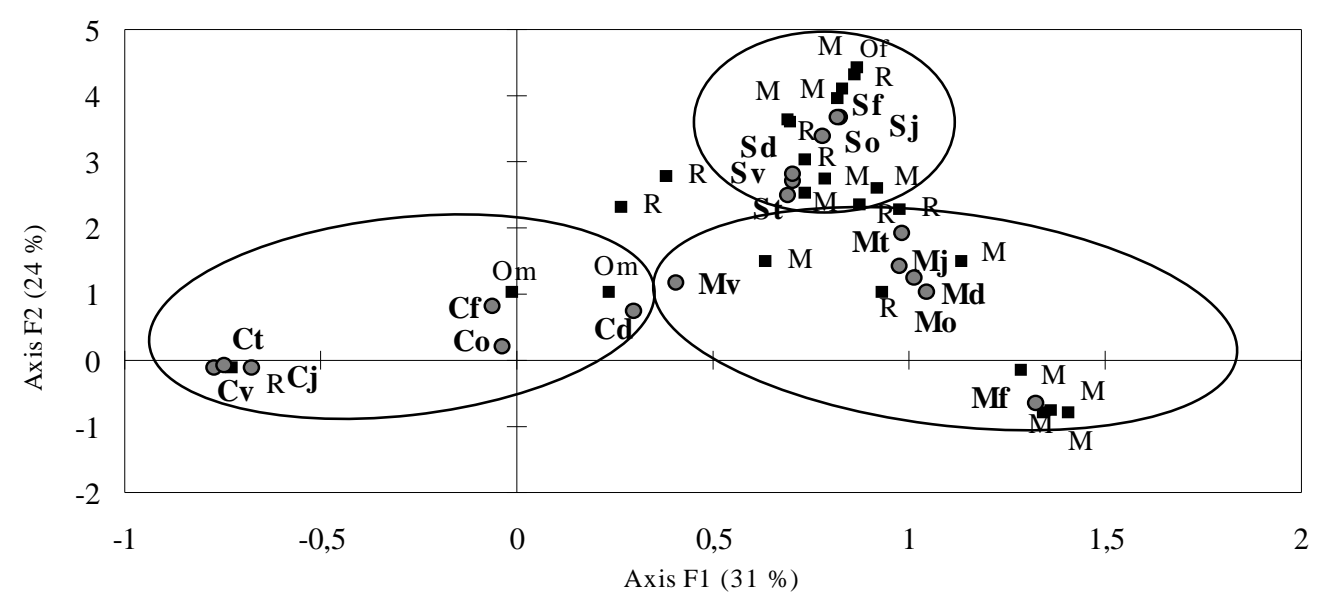

Figure 7 - Factorial correspondence analyses considering the density of the 24 species and their ecological guilds, and the 18 station/month in continental $\mathrm{C}$ and marine $\mathrm{M}$ sectors of the Guaratuba bay, and Barra do Saí lagoon S in the months: v: April; j: June; t: August; o: October; d: December; f: February; and ecological guilds R: resident; M: migrant; Om: marine occasional; Of: freshwater occasional 
The second axis explained $24 \%$ of the inertia, revealing a negative gradient for the density from the bay to the lagoon. According to the species that most contributed to the analysis, sector C, characterized by the resident Anchoa januaria, and sector M, characterized by a marine group of species, mainly Opisthonema oglinum, Anchoa lyolepis and Anchoviella lepidentostole were opposite to the lagoon, characterized by the marine species Eucinostomus argenteus and E. melanopterus and the resident Ctenogobius shufeldti. In this area, only two freshwater species out of the 69, Poecilia vivipara and Geophagus brasiliensis were captured. The residents Atherinella brasiliensis and Sphoeroides greeleyi greatly contributed to an intermediate position between the marine sector of the bay and the lagoon one, and were characteristic of these two areas (Fig. 7).

\section{DISCUSSION}

Geomorphologic parameters are strongly affected by changes in sea level, coastal engineering and other human activities. A rise in sea level involves an increase in lagoon size and depth and in some areas can affect the isolation status with respect to the open sea (Pérez-Ruzafa et al., 2007). The Barra do Saí lagoon and the two sectors of Guaratuba bay differed between them in transparency, salinity, organic matter and silt percentage values. The Barra do Saí lagoon and the marine sector of Guaratuba, both of them closer to the sea, showed greater influence from the salinity factor than the continental sector of the bay. On the other hand, Barra do Saí lagoon was more continental than the internal part of the bay due to the sediments in suspension and even to freshwater contributions coming from the river basins.

The gradients of both species and family richness in the bay indicated the impoverishment of the ichthyofauna from the point of communication with the sea towards the more continental margins of these estuaries, which was perhaps due to the differences in the renewal of seawater there (Bouchereau et al., 2000; Bouchereau and Chaves, 2003). However, it was important to notice that species richness observed at the edges of the bay (50) did not represent the total number of species present at the Guaratuba bay, as Chaves and
Vendel (2001), by using other fishing devices and at different collection depths, recorded 87 species in this same area.

According to the density data, the same species did not dominate in all the samples, stations and sectors. This showed that, despite the proximity between the bay and the lagoon, topography and hydrodynamism played an important role determining the structure of the fish assemblages in each estuary. In fact, during this study, the differences in the diversity and evenness values were registered between the salt marshes in the two sectors of the bay, as well as between the bay and the lagoon. In the bay, the continental sector was less stable than the marine one, with regard to the respective species sets.

The difference in effort in the samplings sites was due to the fact of they had different dimensions, then the way to sample should be different, compelling the reduction in the net size in the lagoon, becoming its use appropriated in each site. In the marine sector, changes in the diversity and evenness noticed at the end of autumn are due to a reduction in the species number and to the presence - mainly in June - of an abundant schooling species, Atherinella brasiliensis. Indeed, Anchoa januaria was the dominant species particularly in certain stations (3 and 6) and months (April and August). During the summer, the increase in schooling fish probably corresponded to the recruitment of juveniles of several species (Vendel et al., 2003), whose reproductive period began in spring (Chaves and Bouchereau, 2000). On the other hand, the diversity and evenness were greater in the salt marshes of the lagoon than in those of the bay, independent of the area or time. This could be allotted to the gregarious behavior of certain freshwater fishes species such the Cichlids and the Poecilids living in the lagoon. Supposedly, in the lagoon the daily replacement of marine species by freshwater ones occurs quickly because of the small volume of water and its proximity to both the river and the sea.

In his bibliographic review, Blaber (2000) was not able to compare the fish abundances in the tropical lagoon-estuarine ecosystems of different sizes due to the lack of data and to the heterogeneity of methods used. Regarding the classification of species into ecological guilds, the ideal procedure would be to combine the ecological, behavioral, physiological and ontogenic characteristics of the 
estuarine species, as suggested by Nordlie (2003), who studied the estuaries in the Gulf of Mexico and North American compared them to temperate estuaries and stressed the need to apply this classification, mainly to the tropical and subtropical estuarine ichthyofauna, using similar collecting techniques and giving importance to the methodology used to study the life history of the species. In the present study, the ichthyofauna was sampled according to the same methodology in two geographically very close ecosystems that were distinct with regard to their size, geomorphology and hydrodynamism. In the bay, the composition of species, as well as their densities, was greater than that observed in the lagoon. This was probably related to: (i) the size difference of the two estuaries, allowing Guaratuba bay to offer a larger amount of habitat and food for its occupants, and/or (ii) the less gregarious behavior of the species occupying the lagoon. The local density relationship was lower in the lagoon, and could be due to the presence of zones that were more favorable to recruitment than those under marine influence, showing the phenomenon of reduced body size (lagoon nanism) already observed in more confined zones (Bouchereau et al., 2000; 2008).

The high densities of the fishes and motile macroinvertebrates in the mangrove vegetation appeared to be related to the greater protection afforded by this vegetation. Thus, the aerial roots, tree trunks, and fallen branches of the mangrove forests attract fish, providing refuge from predation and more food availability (Laegdsgaard and Johnson, 2001). Fish may be more abundant in these habitats, even in the presence of predators, because the increased structural complexity of the tree branches covered by algae affords them more shelter, and thus less risk of predation.

According to Pérez-Ruzafa et al. (2006), several factors are likely to determine this high biodiversity, such as its size, substratum diversity, environmental heterogeneity, and its degree of communication with the open sea. In this study, the fish occupation in the salt marshes according to richness, sediment in suspension and seasonal density gradients along the Guaratuba Bay was linked to the abundances of trophic migrants in the marine sector, as well as to the recruitment of the resident Anchoa januaria in the continental sector. It is known that the most important aspect of this habitat for small juvenile fish is its complex structure that provides maximum food availability and minimizes the incidence of predation (Legendre and Legendre, 1984) associated with the specific local occupation. In the salt marshes of the Barra do Saí lagoon, the fish assemblage did not present a specific organization, even if the richness approached that of the Guaratuba marine sector. It was mainly composed by the migrant (Gerreidae), resident (Gobiidae) and also freshwater (Poecilia vivipara and Geophagus brasiliensis) species with a clearly lower density, which set it in a particular intermediate position under the marine and continental influences. The proportion of ecological guilds also confirmed this because for resident species it was similar to that of the continental sector; while for the occasional species, it was more like that of the marine sector. Indeed, whatever the season, the salt marshes of Barra do Saí lagoon are daily subjected to a double pressure, both continental and marine, which is enhanced by the inputs of freshwater and marine waters sharing a unique channel. These close water incomings from different origin increase the renewal in Barra do Saí in comparison to that of the marine sector of Guaratuba, where Bouchereau and Chaves (2003) supposed a greater inertia of water masses.

The role played by hydrodynamism on the fish distribution in coastal systems has been discussed considering two different neighbor environments. The influence of marine waters was different between Guaratuba Bay and Barra do Saí lagoon, because in the lagoon the marine and freshwater waters mixed faster than in the former as a consequence of the different inputs and outputs of each type of contribution - marine or continental.

A stable environmental gradient determines the persistent extension and penetration of marine species inside the estuary, and reciprocally of freshwater species (Jaureguizar et al., 2003), but in Barra do Saí lagoon, despite its small size, but because of its easy access for both the freshwater and marine fish, it was a sheltered locality for all kinds of occupants. Due to the juxtaposed situation of the water discharge from different origins, the fish assemblage organization looked less stable in the Barra do Saí lagoon than in Guaratuba bay. Variations in the hydrological attributes provoked by the marine or continental water movements would alter the conditions in the lagoon more quickly and at more regular frequencies than those in the bay. 


\section{ACKNOWLEDGEMENTS}

This study was realized with the financial support from the bilateral convention between France and Brazil (CAPES-COFECUB $n^{\circ} 376 / 02$ ). We are grateful to the Department of Zoology of the Universidade Federal do Paraná and to the National Council for Scientific and Technological Development (CNPq).

\section{RESUMO}

Estrutura e organização das assembléias de peixes de águas rasas $(<1,5 \mathrm{~m})$ foram estudadas em dois ecossistemas sul-brasileiros sob influências marinhas ou continentais, uma laguna e uma baía. Dados abióticos foram obtidos para definir a hidrologia dos locais, e descritores bióticos foram avaliados para caracterizar a estrutura das assembléias. Transparência, salinidade e matéria orgânica melhor distinguem os locais. Foram capturadas 69 espécies distribuídas em três guildas ecológicas. Descritores como densidade, diversidade e equitabilidade foram diferentes em cada local. Hidrodinamismo e geomorfologia determinaram a estrutura e a organização das assembléias de peixes nestas águas rasas. Observou-se que variações nos atributos hidrológicos gerados por aportes marinhos ou continentais podem alterar mais rapidamente, e em freqüências mais regulares, as condições na lagoa do que aquelas na baía.

\section{REFERENCES}

Adams S. (1976), Feeding ecology of eelgrass fish communities. T Am Fish Soc, 4, 514-519.

Aranha J. M. R. and Caramaschi, E. P. (1997), Distribuição longitudinal e ocupação espacial de quatro espécies de Cyprinodontiformes no rio Ubatiba, Maricá, RJ, Brasil. Acta Biol Par, 26 (1, 2, $3,4), 125-140$

Austin H. M. (1971), Some aspects of the biology of the rhomboid mojarra Diapterus rhombeus in Puerto Rico. B Mar Sci. 21(4), 886-903.

Axelrod H. R. and Schultz, L. P. (1990), Range: Amazon and Orinoco Basins to Rio de La Plata Basin, Rio Grande do Sul, Uruguai. Handbook of Tropical Aquarium Fishes. T.F.H. Publications INC. Neptume City, USA. 718 pp.
Blaber S. J. M. (2000). Tropical Estuarine Fishes. Ecology, Exploitation and Conservation. Ed. Blackwell Science, Oxford, 372 pp.

Bonnet B. R. P., Lana, P. C. and Guiss, C. (1994), Influência da gramínea Spartina alterniflora sobre a distribuição e densidade de Neritina virginea (Gastopoda: Neritidae) em marismas da Baía de Paranaguá (Paraná, Brasil) Nerítica, 8(1-2), 99-108.

Bouchereau J.-L., Guélorget, O. Vergne, Y. and Perthuisot, J. P. (2000), L'ichtyofaune dans l'organisation biologique d'un système paralique de type lagunaire: le complexe des étangs du Prévost et de l'Arnel (Languedoc, France) Vie Milieu Life and Environment, 50(1), 19-27.

Bouchereau J.-L. and Chaves, P. T. C. (2003), Ichthyofauna in the ecological organization of a Southwest Atlantic ecosystem: the bay of Guaratuba, Brazil (2552'S; 48 $\left.39^{\circ} \mathrm{W}\right)$ Vie Milieu Life and Environment 53(2/3), 103-110.

Bouchereau J.-L., Chaves, P. T. C. and Monti, D. (2008), Factors Structuring the Ichtyofauna Assemblage in a Mangrove Lagoon (Guadeloupe, French West Indies). J Coast Res. 24(4), 969-982.

Cervigón F., Cipriani, R., Fischer, W., Garibaldi, L., Hendrickx, M. Lemus, A. J., Márquez, R., Poutiers, J. M. Robaina, G. and Rodriguez, B. (1992), Fichas FAO de identificación de especies para los fines de la pesca. Guía de campo de las especies comerciales marinas y de aquas salobres de la costa septentrional de Sur América. FAO, Rome. 513 pp.

Cervigón F. (1994), Los peces marinos de Venezuela. Volume 3. Fundación Científica Los Roques, Caracas, Venezuela. 295 pp.

Chao L. N. (1978), Sciaenidae. In-W. Fischer (ed.) FAO species identification sheets for fishery purposes. West Atlantic (Fishing Area 31). Vol. 4, FAO, Rome.

Chaves P. T. C. and Vendel, A. L. (1997), Indicadores reprodutivos das espécies de Citharichthys (BLEEKER) (TELEOSTEI, PLEURONECTIFORMES) na Baía de Guaratuba, Paraná, Brasil. Rev Bras Zool, 14 (1), 73-79.

Chaves P. T. C. and Vendel, A. L. (1998), Feeding habits of Stellifer rastrifer (PERCIFORMES, SCIAENIDAE) at Guaratuba Mangrove, Paraná, Brazil. Braz Arch Biol Techn, 41 (4), 423-428.

Chaves P. T. C. and J.-L. Bouchereau (1999), Biodiversité et dynamique des peuplements ichtyiques de la mangrove de Guaratuba, Brésil. Oceanol Acta, 22(3), 353-364.

Chaves P. T. C., Bouchereau, J. -L. (2000), Use of mangrove habitat for reproductive activity by the fish community in the Guaratuba Bay, Brazil. Oceanol Acta, 23(3), 273-280.

Chaves P. T. C. and Vendel, A. L. (2001), Nota complementar sobre a composição ictiofaunística da Baía de Guaratuba, Paraná, Brasil. Rev Bras Zool (suppl. 1), 349-352. 
Collette B. B. (1978), Hemiramphidae. In-W. Fischer (ed.) FAO species identification sheets for fishery purposes. Western Central Atlantic (Fishing Area 31), Vol. 2, FAO, Rome.

Collette B. B. and Nauen, C. E. (1983), FAO species catalogue. Vol. 2. Scombrids of the world. An annotated and illustrated catalogue of tunas, mackerels, bonitos and related species known to date. FAO Fisheries Synopsis. 125 (2), 137 pp.

Duque-Nivia G., Acero, A., Santos-Martinez, A. and Rubio, E. (1996), Food habits of the species of the genus Oligoplites (Carangidae) from the Cienaga Grande de Santa Marta-Colombian Caribbean. Cybium, 20 (3), 251-260.

Edgar G. J. and Shaw, C. (1995), The production and trophic ecology of shallow-water fish assemblages in southern Australia. I. Species richness, size-structure and production of fishes in Western Port, Victoria. $J$ Exp Mar Biol Ecol, 194, 53-81.

Elliott M. and Dewailly, F. (1995), The structure and components of European estuarine fish assemblages. Nnet J Aquat Ecol, 29(3-4), 397-417.

Figueiredo J. L. and Menezes, N. A. (2000), Manual de peixes marinhos do sudeste do Brasil. VI. Teleostei (5). Museu de Zoologia, USP, Brasil. 116 pp.

Folk R. L. and Ward, W. C. (1957), Brazos River Bar, a study in the significance of grain size parameters. $J$ Sediment petrol, 27(1), 3-26.

Guélorget O. and Perthuisot, J. P. (1983), Le domaine paralique. Expressions géologiques, biologiques ed économiques du confinement. Travaux du Laboratoire de Géologie. Presse de l'Ecole Normale Supérieure, Paris, $136 \mathrm{pp}$.

Heemstra P. C. and Randall, J. E. (1993), FAO species catalogue. Vol. 16. Groupers of the world. (Family Serranidae, Subfamily Epinephelinae). An annotated and illustrated catalogue of the grouper, rockcod, hind, coral grouper and lyretail species known to date. FAO Fisheries Synopsis 16, 125.

Jaureguizar A. J., Mennin, R., Bremec, C., Mianzan, H. and Lasta, C. (2003), Fish assemblage and environmental patterns in the R1o de la Plata estuary. Estuar Coast Shelf S, 56, 921-933.

Juanes F., Marks, R. E., McKown, K. A. and Conover, D. O. (1993), Predation by age-0 bluefish on age-0 anadromous fishes in the Hudson River Estuary. $T$ Am Fish Soc, 122 (3), 348-356.

Keith P., Le Bail, O. Y. and Planquette P. (2000), Atlas des poissons d'eau douce de Guyane tome 2, fascicule I). Publications scientifiques du M.N.H.N, Paris, 286 pp.

Lana P. C. and Guiss, C. (1991), Influence of Spartina alterniflora on the structural and temporal variability of macrobenthic associations in a tidal flat of Paranaguá Bay Southeastern Brazil). Mar Ecol-Prog Ser, 73, 231-244.
Laegdsgaard P. and Johnson, C. R. (1995), Mangrove habitats as nurseries unique assemblages of juvenile fish in subtropical mangroves in eastern Australia. Mar Ecol-Prog Ser, 126, 67-81.

Laegdsgaard P. and Johnson, C. (2001), Why do juvenile fish utilise mangrove habitats? J Exp Mar Biol Ecol, 257, 229-253.

Legendre L. and Legendre, P. (1984), Ecologie Numérique: le traitement multiple des données écologiques. Masson PUQ, Paris, 270 pp.

Mariani, S. (2001), Can spatial distribution of Ichthyofauna describe marine influence on Coastal lagoons? A central Mediterranean case study. Estuar Coast Shelf S, 52, 261-267.

Maugé L. A. (1986), Gobiidae. In: Daget J., Gosse, JP., Thys van den Audenaerde, D. E. F. (eds.). Cheklist of the freshwater fishes of Africa CLOFFA. ISNB, Brussels, MRAC, Tervuren and ORSTOM, Paris. 2, 335-388.

Mazzoni R., Petito, J. and Miranda, J. C. (2000), Reproductive biology of Genidens genidens, a catfish from the Maricá Lagoon, RJ. Cien Cult, 52 (2), 121126.

Menezes N. A. and Figueiredo, J. L. (1980), Manual de peixes marinhos do Sudeste do Brasil. IV Teleostei 3. São Paulo, Museu de Zoologia, USP, 96 pp.

Menezes N. A. and Figueiredo, J. L. (1985), Manual de peixes marinhos do Sudeste do Brasil. V Teleostei (4). São Paulo, Museu de Zoologia, USP, 105 pp.

Miller G. C. and Richards, W. (1978), Triglidae. In: Fischer, W. Ed. FAO species identification sheets for fishery purposes. West Atlantic Fishing Area 31. FAO, Rome. Vol. 5. pag.var.

Morin B., C. Hudon and Whoriskey, F. G. (1992), Environmental influences on seasonal distribution of coastal and estuarine fish assemblages at Wemindji, eastern James Bay. Environ Biol Fish, 35, 291-229.

Nelson J. S. (1994), Fishes of the world. 3rd edition, John Wiley and Sons, New York, 600 pp.

Nordlie F. G. (2003), Fish communities of estuarine salt marshes of eastern North America, and comparisons with temperate estuaries of other continents. Rev Fish Biol Fisher, 13, 281-325.

Pauly D. (1991), Growth of the checkered puffer Sphoeroides testudineus: postscript to papers by Targett and Pauly and Ingles. Fishbyte, 9(1), 19-22.

Paterson A. W. and Whitfield, A. K. (1997), A stable carbon isotope study of the food-web in a freshwaterdeprived South African estuary, with particular emphasis on the ichthyofauna. Estuar Coast Shelf $S$, 45, 705-715.

Pérez-Ruzafa A., García-Charton, J. A., Barcala, E. and Marcos, C. (2006), Changes in benthic fish assemblages as a consequence of coastal works in a coastal lagoon: The Mar Menor Spain, (Western Mediterranean). Mar Pollut Bull. 53 107-120. 
Pérez-Ruzafa A., Mompeán, M. C. and Marcos, C. (2007), Hydrographic, geomorphologic and fish assemblage relationships in coastal lagoons. Hydrobiologia. 577: 107-125.

Randall J. E. (1967), Food habits of reef fishes of the West Indies. Studies in Tropical Oceanography. Miami, 5, 665-847.

Robert M. C. and Chaves, P. T. C. (2001), Observações sobre o ciclo de vida da corvina, Micropogonias furnieri (Desmarest) (Teleostei, Sciaenidae), no litoral do Estado do Paraná, Brasil. Rev Bras Zool, 18(2), 421-428.

Robins C. R. and Ray, G. C. (1986), A field guide to Atlantic coast fishes of North America. Houghton Mifflin Company, Boston, U.S.A. 354 pp.

Saccardo S. A., Rossi-Wongtschowski, C. L. D. B. Cergole, M. C. and Bittencourt, M. M. (1988), Age and growth of the southeastern Brazilian sardine, Sardinella brasiliensis, 1981-1983. Bol. Inst. Oceanogr. 36(1/2), 17-35.

Sierra L. M., Claro, R. and Popova, O. A. Eds (1994), Alimentacion y relaciones tróficas. p. 263-284. In: Rodolfo Claro. Ecología de los Peces Marinos de Cuba. Instituto de Oceanología Academia de Ciencias de Cuba and Centro de Investigaciones de Quintana Roo, México.

Silvano R. A. M. (2001), Feeding habitats and interspecific feeding associations of Caranx latus (Carangidae) in a subtropical reef. Environ biol fish. 60, 465-470.

Torres R., Fagherazzi, S., Proosdij, D. and Hopkinson, C. (2006), Salt marsh geomorphology: Physical and ecological effects on landform. Estuar Coast Shelf $S$, 69, 309-310.
Vendel A. L. and Chaves, P. T. C. (1998), Alimentação de Bairdiella ronchus (Cuvier) (Perciformes, Sciaenidae) na Baía de Guaratuba, Paraná, Brasil. Rev Bras Zool, 15(2), 297-305.

Vendel, A. L., Spach, H. L., Lopes, S. G. and Santos, C. (2002). Structure and Dynamics of Fish Assemblages in a Tidal Creek Environment. Braz Arch Biol Techn, 45(3): 365-373.

Vendel, A. L., Lopes, S. G., Santos, C and Spach, H. L. (2003). Fish assemblages in a tidal flat. Brazilian Archives of Biology And Technology. 46(2), 233-242.

Whitehead P. J. P. (1985), FAO species catalogue. Clupeoid fishes of the world. An annotated and illustrated catalogue of the herrings, sardines, pilchards, sprats, shads, anchovies and wolf-herrings. Part 1. Chirocentridae, Clupeidae and Pristigasteridae. FAO Fisheries Synopsis 125. Vol. 7, Pt. 1: 303pp.

Whitehead P. J. P., Nelson, G. J. and Wongratana, T. (1988), FAO species catalogue. Clupeoid fishes of the world (Suborder Clupeoidei). An annotated and illustrated catalogue of the herrings, sardines, pilchards, sprats, shads, anchovies and wolf-herrings. Part 2 - Engraulididae. FAO Fisheries Synopsis, 7 (125) Pt. 2: 579pp.
Received: February 27, 2009; Revised: October 05, 2009; Accepted: July 23, 2010. 